\title{
ВИВЧЕННЯ НАВЧАЛЬНОЇ ДИСЦИПЛІНИ «МЕДИЧНЕ ТА ФАРМАЦЕВТИЧНЕ ТОВАРОЗНАВСТВО» МАГІСТРАМИ ДИСТАНЦІЙНОЇ ФОРМИ НАВЧАННЯ
}

\author{
Ю. А. Равлів, В. Р. Мах, Я. В. Соловей \\ Тернопільський національний медичний університет \\ імені І. Я. Горбачевського МОЗ Украӥни
}

У статті проаналізовано необхідність вивчення навчальної дисципліни «Медичне та фармацевтичне товарознавство» для магістрів дистанційної форми навчання.

\section{LEARNING THE SUBJECT OF MEDICAL AND PHARMACEUTICAL COMMODITY SCIENCE BY MASTERS OF DISTANCE LEARNING}

\author{
Yu. A. Ravliv, V. R. Makh, Ya. V. Solovey \\ I. Horbachevsky Ternopil National Medical University
}

The need to study the subject of Medical and Pharmaceutical Commodity Science for masters of distance learning is analyzed in the article.

Вступ. Необхідність поглибленого вивчення товарознавства в практиці підготовки фахівців сестринського профілю, зокрема медичних сестер, які найближче знають і стикаються з асортиментом виробів медичного призначення, потребує більш детального вивчення та розуміння.

Вперше в світі товарознавство фармацевтичних засобів рослинного та тваринного походження почали викладати в 1549 р. у Падуанському університеті (Італія), де й було відкрито першу кафедру [1].

Основна частина. На кафедрі управління та економіки фармації з технологією ліків Тернопільського національного медичного університету імені І. Я. Горбачевського МОз України навчання студентів здійснюється з дисципліни «Медичне та фармацевтичне товарознавство» для студентів-магістрів за спеціальністю 223 «Медсестринство» другого (магістерського) рівня вищої освіти дистанційної форми навчання. Ця дисципліна надає знання про споживчі властивості медичних та фармацевтичних товарів, а також студенти дізнаються про асортимент товарів, їх класифікацію та кодування, стандартизацію та товарознавчі операції. Студенти вивчають і розрізняють медичні та

() Ю. А. Равлів, В. Р. Мах, Я. В. Соловей, 2019 фармацевтичні товари, а також їх основні принципи та завдання. Медичне та фармацевтичне товарознавство надає інформацію студентам про нормативну документацію на товари аптечного асортименту, класифікацію та кодування товарів, а також навчає студентів основним етапам товарознавчого аналізу товарів аптечного асортименту і аспектам (асортимент, пакування, маркування, транспортування та зберігання) медичних виробів.

Фахівці повинні вміти: перевірити відповідність товару документації, що його супроводжує, встановити відповідність пакування лікарського засобу його фізико-хімічним властивостям, перевірити відповідність маркування вимогам нормативної документації, зробити висновок про терміни та умови зберігання, правила транспортування тощо [2].

Товарознавці забезпечують рух товарів від виробників до споживачів з урахуванням асортиментної, якісної, кількісної та вартісної характеристик товару, а також запитів споживачів.

Сам термін «товарознавець» в буквальному сенсі може бути витлумачений як «знавець товару» або «суб'єкт, що знає товар». Саме глибоке знання товарів відрізняє товарознавців від інших фахівців медичної галузі. 
Товарознавці здійснюють професійну діяльність у тісній взаємодії з технологами та маркетологами. Перші забезпечують виробництво продукції, яка поки що не $€$ товаром. Перехід продукції з галузі виробництва в галузь обігу означає, що вона отримала статус товару, з об'єкта технологічної діяльності перетворилася на об'єкт товарознавчої діяльності. Товарознавці входять до складу комерційних відділів, відділів реалізації або інших структурних підрозділів промислових підприємств, що випускають продукцію медичного призначення, а також підприємств оптової та роздрібної аптечної мережі.

Можна виділити два основних напрямки товарознавчої діяльності: технологічний, що забезпечує технологію руху товарів, і організаторський, націлений на стимулювання збуту, виявлення попиту і ринків збуту, організацію закупівель товарів.

Однак діяльність товарознавців на відміну від маркетологів більше пов'язана з функціями, виконання яких вимагає досконалого знання споживчих властивостей товарів. Разом із тим товарознавцям-технологам і організаторам притаманний ряд загальних посадових обов'язків, виконання яких вимагає певних знань, умінь і навичок товарознавства.

Магістр-товарознавець повинен знати в галузі товарознавства:

- емпіричні та аналітичні методи, що дозволяє найраціональніше розбиратися у всьому різноманітті асортименту, засобів і способів збереження якості й кількості медичних та фармацевтичних товарів у процесі руху товару;

- асортимент медичних і фармацевтичних товарів (товарну номенклатуру), показники, які його характеризують, способи і етапи управління асортиментом;

- напрямки розвитку і вдосконалення асортименту;

- номенклатуру споживчих властивостей медичних і фармацевтичних товарів та показників, критерії їх вибору при оцінці якості;

- кількісні характеристики одиничних екземплярів медичних і фармацевтичних товарів та товарних партій, правила відбору проб із партій;

- фактори, що впливають на формування і збереження якості медичних і фармацевтичних товарів;

- види втрат і причини їх виникнення, порядок списання;

- види, функції, форми і засоби товарної інформації;

- товарознавчі характеристики товарних груп і конкретних медичних і фармацевтичних товарів.
Теоретичні знання реалізуються через певні товарознавчі навички, тому товарознавець повинен вміти:

- класифікувати, аналізувати і узагальнювати результати оцінки товарів за різними ознаками (складом, показаннями, протипоказаннями, технічними характеристиками тощо) для більш повного задоволення попиту споживачів різних сегментів ринку, а також для виявлення споживчих переваг і забезпечення конкурентоспроможності товарів медичного призначення;

- визначати і аналізувати показники асортименту для досягнення раціональної асортиментної політики оптової або роздрібної ланки аптечної мережі з урахуванням напрямку розвитку й удосконалення товарів однотипних груп;

- оцінювати якість медичних і фармацевтичних товарів шляхом вибору найприйнятнішої номенклатури властивостей і показників, визначення фактичних значень і зіставлення з регламентованими вимогами нормативно-технічної документації (НТД);

- проводити діагностику дефектів, виявляти причини їх виникнення для прийняття рішень про можливість (або неможливість) пред'явлення претензій і матеріальних позовів винним особам, а також використання для профілактики та лікування пацієнтів;

- ідентифікувати товарні партії, розраховувати і відбирати проби відповідно до встановлених вимог НТД; - визначати приймальні й бракувальні числа для проведення приймально-здавального та поточного контролю якості відповідно до встановлених вимог;

- проводити вимірювання медичних і фармацевтичних товарів та товарних партій для встановлення їх кількісних характеристик при обліку на різних етапах руху товару;

- враховувати формуючі фактори для прогнозування якості й конкурентоспроможності медичних і фармацевтичних товарів, а також для оцінки можливості виробника випускати товари, якість яких відповідає потребам конкретного сегмента ринку;

- регулювати фактори, що впливають на збереження якості медичних і фармацевтичних товарів при зберіганні, транспортуванні та застосуванні;

- контролювати створення та підтримку кліматичного та санітарно-гігієнічного режимів зберігання медичних і фармацевтичних товарів;

- брати участь у виборі найприйнятніших видів торгового обладнання для зберігання, підготовки до продажу та реалізації з урахуванням особливостей 
товарів або товарних груп, для яких це обладнання буде призначено;

- розробляти і здійснювати заходи щодо запобігання та зниження втрат;

- забезпечувати підготовку товарів до реалізації для формування належної якості й кількості, поліпшення товарного вигляду і попередження реалізації товарів, які не відповідають за якістю встановленим вимогам;

- працювати з товарно-супровідними документами для визначення та/або перевірки всіх характеристик товарної партії, виробника і постачальника, інших відомостей, необхідних для подальшої роботи з товаром;

- виявляти за допомогою різних засобів основну, комерційну та споживчу інформацію для найповнішого ознайомлення з товаром і створення споживчих переваг, що дозволяє стимулювати збут товарів;

- ідентифікувати товар за допомогою маркування різних видів, розшифровувати інформаційні знаки на маркуванні та товарно-супровідних документах для надання споживачам достатньої та достовірної інформації;

- працювати з конкретними медичними та фармацевтичними товарами - ідентифікувати їх з певною асортиментною групою і видом, оцінювати якість,

\section{СПИСОК ЛІТЕРАТУРИ}

1. Гридасов В. І. Фармацевтичне і медичне товарознавство : навчальний посібник для студентів вищих навчальних закладів / В. І. Гридасов, Л. М. Оридорога, О. В. Винник. - Харків : Видавництво НФАУ : Золоті сторінки, 2002. - 160 с.

2. Медичне та фармацевтичне товарознавство : підручник : у 2-х ч. / І. І. Баранова, С. М. Коваленко, Ю. О. Безпала та ін. - Харків : НФаУ : Оригінал, 2016. - Ч. 2. - 304 с. забезпечувати збереження товарів на всьому шляху їх руху до споживача $[3,4]$.

Безумовно, для виконання товарознавчих функцій і операцій магістр повинен володіти спеціальними знаннями в галузі класифікації фармацевтичних товарів, впливу факторів зовнішнього середовища i упаковки на фармацевтичні товари, прогнозування термінів зберігання, структури споживчих властивостей товарів, маркування, стандартизації, фармацевтичного маркетингу тощо.

Під час навчання у магістратурі студенти-магістри працюють над написанням магістерської роботи. Наукова робота $є$ одним із видів навчання студентів, де вони показують рівень засвоєння знань, практичних вмінь та навиків, отриманих у ході навчання в університеті.

Висновки. Завдяки вивченню навчальної дисципліни «Медичне та фармацевтичне товарознавство» магістри будуть використовувати отримані знання та будуть проводити товарознавчий аналіз виробів медичного призначення вітчизняного та іноземного фармацевтичного ринку з метою порівняння різних країн-виробників, видів, а також будуть проводити анкетування українською та іноземною мовами для визначення та встановлення важливих показників, які будуть висвітлені у магістерській роботі.

3. Васнецова О. А. Медицинское и фармацевтическое товароведение : учебник / О. А. Васнецова. - 3 издание, переработанное и дополненное. - М. : Авторская Академия, 2016. - 424 c.

4. Demyanenko D. V. Medical and pharmaceytical commodity science: practical manual / D. V. Demyanenko, V. G. Demyanenko. - Kharkiv : NUPh, 2011. - 257 p.

Отримано 05.10.19 